\title{
Cohesion and competitiveness of the European Union at strategic level
}

\author{
Zoltán Eperjesi \\ Metropolitan Public Domain Maintenance Ltd., Buckinghamshire \\ zoltan.eperjesi76@gmail.com
}

SUMMARY

\begin{abstract}
After the relaunchment of the Lisbon strategy, the cohesion policy of the EU concentrates even stronger on the establishment of the knowledge based economy, on R\&D activities and innovations. In the first chapter I demonstrate the funds division of the convergence and regional competitiveness targets in the financial perspective between 2007-2013. The first sheet shows unambiguously that the new member states from Middle-Eastern Europe and the Mediterranean countries spend their funds on convergence and cohesion issues. The situation is contrary in the highly developed Western-European countries, in the core regions, where decisive part of the funds are spent on competitiveness issues. In the second chapter of the study I present the Europe 2020 strategy of the EU, that is a crucial paradigm change in the European strategy-making. While the Lisbon strategy focused on the social cohesion of the European Union, the Europe 2020 strategy strives the fostering of the European competitiveness. In the third part of the study I make a comparison how the funds-allocation altered during the two financial perspectives.
\end{abstract}

Keywords: “Europe 2020” strategy, competitiveness, cohesion, research and development, knowledge based economy

\section{ÖSSZEFOGLALÓ}

A lisszaboni stratégia újraindításával a kohéziós politika sokkal erősebben koncentrál a tudásalapú gazdaság megteremtésére, a kutatásfejlesztés, valamint az innováció fontosságára. Az elsö pontban szemléltem a konvergencia és a regionális versenyképesség forrásainak megoszlását a 2007-2013-ig terjedö idöszakban. Az elsö számú táblázatból jól megfigyelhetö, hogy a közép-kelet európai volt szocialista országok, valamint a mediterrán országok, leszámitva Franciaországot és Spanyolországot, a rájuk esö forrásokat kohéziós és konvergencia célkitüzésekre költik. Fordított a helyzet az EU fejlett magrégióiban, ahol a források meghatározó hányadát a versenyképesség fokozására használják fel.

A tanulmány második pontjában taglalom az Európai Unió Európa 2020 elnevezésü stratégiáját, amely jelentős paradigmaváltást jelent a lisszaboni stratégiához képest. Mig a lisszaboni stratégia az unió szociális kohézióját tartotta elsőszámú prioritásának, addig az Európa 2020 stratégia a versenyképesség növelésére helyezi a fö hangsúlyt.

A tanulmány harmadik pontjában ismertetem a 2000-20006-ig, valamint a 2007-2013-ig terjedö költségvetési időszakok forrásallokációjában bekövetkezett lényeges struktúrális különbségeket.

Kulcsszavak: Europe 2020 stratégia, versenyképesség, kohézió, $K+F$, tudásalapú gazdaság

\section{COHESION AND COMPETITIVENESS IN THE EUROPEAN UNION}

The economic, social and territorial cohesion is based on three strategic directives during the period between 2007-2013. These strategic directives are as follows:

1. Increasing the attractiveness of the member states, regions and towns by improving their access, securing the appropriate quality and level of services, maintenance of the environment

2. Strengthening the innovations, the enterpreunial spirit and the knowledge based economy by maintaining the research and development capacities, including the new information and communication technologies.

3. Creating more and better jobs so that more and more people are attracted by entrepreneurship, developing the absorption capacity of enterprises and employees and increasing investments in human resources (Resolution of the European Council for strategic guidelines concerning cohesion (2006/702/EK).

The following principles are to be taken into consideration so that the renewed Lisbon strategy can be accomplished. The cohesion policy within the renewed Lisbon strategy strongly concentrates on the creation of knowledge based economy, research and development and innovation. Sustainable development is further maintained by harmonising the coincidence between the economic, social and environmental protection dimensions. The national development policies regard the environment protection as a vehicle generating growth that strengthens competitiveness and increases employment. The environmental aspect is already considered in the preparation phase of the programmes. Furthermore the equality between genders and antidiscrimination are emphasized.

In the framework of the Cohesion Fund and the aim of convergence the member states and regions entitled to maintenance have to prefer those European integration projects referring to their territory. Special attention has to be paid to cross-border connections within the transEuropean networks transportation projects. In order to improve regional development and the effectiveness of transportation projects, the geographically isolated regions have to be involved in the TEN transportation projects.

The renewed Lisbon strategy contains considerable changes in comparison to the original concept. As the original Lisbon strategy concentrated on the cohesion, the renewed version prefers competitiveness to cohesion.

Member-states being entitled to subsidies from the Cohesion and Structural Funds, use the funds of the Cohesion Fund to the financing of their TEN projects, while they withdraw funds from the Structural Funds to 
finance economic fostering projects (Resolution of the European Council for strategic guidelines concerning cohesion (2006/702/EK).

The growth of the EU and creation of new jobs require the shift of the economy into the direction of knowledge based activities. The EU has a big gap on the field of research and development compared to the USA and Japan. The private sector needs to struggle an even bigger lack. The Lisbon strategy established that the member-states should spend $3 \%$ of their GDP on R\&D but this ratio is not fulfilled within the EU. The innovation gap of the EU compared to other global economic players becomes deeper and deeper. Unfortunately the commercialisation of the technological developments does not occur in the appropriate measure. The broadening of the national and regional capacities has to be fostered so that technology and knowledge are really used in the economy. The integration of the small- and medium sized companies into research and development activities is of utmost importance as these companies employ two-third of the workforce. It is rather important to co-ordinate the R\&D activities of the state and the private sector so that duplicities can be avoided and synergy effects can be used. The cohesion policy aids the regions to establish their research and innovation capacities. The regions may take part in the European Research Space in that way. The strategy of the integration referring to cohesion formulates the following directives:

- Strengthening of the co-operation among companies, research institutions and universities. Maintenance of regional and trans-regional clusters.

- Maintenance of the R\&D activities and technology transfers within the SME sector. It is aimed that the SME sector has access to R\&D services rendered by state owned research institutions.

- Maintenance of the trans-regional and trans-national initiatives. The aim is to foster the research co-operation and the efficiency on research fields prioritised by the EU.

- The research infrastructure and the human resources have to developed on the fields disposing of considerable growth potential (Resolution of the European Council for strategic guidelines concerning cohesion (2006/ 702/EK).

Analysing the statistics it turns out that the funds allocation in the former socialist Middle-Eastern European countries refers almost totally to convergence goals. Among the 10 Middle-Eastern European countries only the Czech Republic and Slovakia spend $2-5 \%$ of the available funds on regional competitiveness and employment goals. Hungary uses the total fund, 25.307 million EUR for convergence and cohesion goals. Germany spends $59 \%$ of the allocated funds for convergence and cohesion goals during the period between 2007 and 2013. It is not the case in France, where $68 \%$ of the funds are spent on strengthening the competitiveness. The funds allocation of the different member countries demonstrates well the formation of a two-speed Europe. As the Middle-Eastern European and Mediterranean member countries allocate only a negligible part of their funds to competitiveness - apart from Spain and Italy with 33 and 26\% - the
Benelux countries, Denmark, Ireland, France spend considerable part of the funds to enhance competitiveness.

During the budget period 2007-2013 the EU spends 342757567465 EUR on convergence and regional competitiveness and employment purposes, from which amount innovations have a stake of 25\% (85 198 EUR). The old member states allocate 48 billion EUR to innovations, as the 12 newcomers allocate 35 billion EUR for this purpose. Comparing the actual data with those of the period 2000-2006, it can be assessed that the total amount allocated to innovations doubled. During the period 2000-2006 25502 million EUR were spent on innovations that made up $11 \%$ of the total allocation on convergence and competitiveness purposes (224 441 million EUR).

It can be established that $60 \%$ of the financial sources for convergence targets are spent in the new member-states, as $40 \%$ of the funds are allocated in the old member-states. The situation is just the contrary in case of the regional competitiveness. $94 \%$ of the financial sources fall on the old member-states and the remaining $6 \%$ of the funds are allocated among the six newcomers. The cohesion policy of the budget period between 2007 and 2013 requires a strategic approach that integrates the growth strategies at European, regional and local levels. The new concept strives to secure that the different sectors are developed simultaneously and not separately. One of the main characteristics of the new budget period is that innovation occupies the focus point of cohesion policy. The regions are also encouraged to elaborate their own innovation strategy.

The renewed Lisbon strategy and the cohesion policy emphasize the importance of innovations. Innovations are regarded as the key element of struggling European problems.

\section{EUROPE 2020 STRATEGY}

The Europe 2020 strategy is based on three decisive priorities:

- securing the continuous growth, whose essence is the knowledge and innovation based economy;

- sustainable development, that necessitates the raw material saving, competitive economy considering environment protection aspects;

- endogenous economy based on social development requiring high employment and social and territorial cohesion.

The European Commission established the targets

to be reached by 2020 . The 5 targets are as follows:

- employment of $75 \%$ of people aged between 20 and 64 years;

- $3 \%$ of the total GDP of the European Union should be spent on research and development;

- fulfilment of the „20/20/20” climate energy goals;

- number of children leaving school before ending should be reduced under $10 \%$ and $40 \%$ of the young generation should dispose of diploma;

- the number of people living under the poorness level should be reduced by 20 million people by 2020 (Communication from the Commission, Europe 2020). 
The enlisted goals are interconnected and are of crucial importance to the future of the EU. The member states need to integrate the targets set by the EU into their own target hierarchy so that the EU may successfully manage the challenges of globalization.

The goals are linked to the strategic growth priorities but they do not involve all the action programmes at national, international or union level that contribute to growth. The European Commission launched 7 decisive initiatives catalysing the priorities:

- „Innovation union”: amelioration of the framework circumstances of R\&D financing, easing of accession to financing so that the innovative ideas may be converted into new products and services generating growth.

- "Youth in move": Increasing of the standards of education systems, measures enabling young people to enter the labour market.

- „Digital Europe”: Introduction of high speed internet and the unified European digital market.

- „Resource efficient Europe”: Economic growth needs to be separated from increasing raw material volumes. The forth initiative forces the trend to low carbon usage, energy efficiency, broadening of renewable energy sources and modernisation of shipping.

- "Industry policy elaborated to globalization": Amelioration of business atmosphere, especially for small- and medium sized enterprises, establishment of competitive industry basis capable of constant development.

- "Establishment of new jobs and skills": Modernisation of the labour market, expansion of the philosophy of lifelong learning, intensification of labour mobility, matching of labour demand and supply.

- "European platform against poverty": This initiative envisages the social and territorial cohesion, so that growth and new jobs contribute to the expanding welfare of widespread social groups and the social declassified groups may be reintegrated into the society (Communication from the Commission, Europe 2020).

The 7 initiatives refer to all member states. The vehicles at EU level, first of all the common market, the financial institutions, the external policy vehicles must be involved so that the Europe 2020 strategy may be achieved. Reforms of the financial systems, consolidation of the budget are of utmost importance. The Europe 2020 strategy is based on two columns, firstly on the priorities and goals, secondly on country reports. Country reports provide orientation to member states how they should elaborate strategies to reach growth. The European Council manages the whole strategic package. The European Commission constantly monitors the measures taken to accomplish targets and proposes modifications if necessary. The European Parliament is responsible for mobilising people and participating in lawsuit concerning initiatives. This partnership approach should be extended to the commissions of the EU, to national parliaments, to national, regional and local institutions, to social partners and civil organisations so that the planned vision can be easily perceived.

\section{STRUCTURAL WEAKNESSES OF THE EU GOT TO SURFACE}

Combating the current crises is a big challenge but converting the structure predominant before crises is an even harder task to solve. Even before the crises, there were fields where the EU was lagging behind its competitors. The union's average growth rate was below of the competing economic power centres, which is firstly due to lower productivity. The productivity gap is explained by low R\&D investments and low use of information technology. Absorption capacity and economic dynamism also lag behind in comparison to the other participants of the triad. The employment rate of $69 \%$ of the EU concerning the population between 20 and 64 years differs negatively from other economic power centres. Only $46 \%$ of the older European generation aged between 55-64 years work in spite of the average $62 \%$ value of the USA and Japan. Furthermore the European workers work 10 working hours less than their American and Japanese colleagues (Communication from the Commission, Europe 2020).

Severe demographic problems turn up as well. The pensioning of the baby-boom generation parallel draws the reduction of the active working population. The proportion of the population above 60 years grows twice as rapid, as before 2007 . The decreasing number of active population, the rising unemployment rate and the drastic growing proportion of pensioners enormously challenge the welfare systems of European countries.

\section{Global challenges turn up}

Europe needs to assess its structural weaknesses and treat them if it wants to maintain its position not mentioning the formerly set first global place. The national economies are overwhelmingly interconnected; the definition of interdependence became one of the main characteristics of world economy. The EU will continuously profit from the open economies of its member states, but it needs severely consider the intensifying competition arising from the newly industrialized countries. Countries having reached their dependence in the 1950-1960 years oriented their economies to knowledge and service basement and production with high R\&D value added. These countries like Singapore, Malaysia, South-Korea converted their economies formerly based on agriculture and primary industries into post-industrial economy characterized by highly developed informationcommunication sector, R\&D centres.

It is to be mentioned that the state played a crucial role in safeguarding and maintaining fledgling industries. China and India seem to follow the same way of economic development. Certainly in case of these two countries we cannot speak of knowledge based economy covering the whole country because $60-70 \%$ of the population are engaged in agriculture and the state of infrastructure is miserable. It cannot be denied that investments into the R\&D sectors enable the emerging economies to integrate into the international labour division and to acquire a forthcoming position in the value chain. On one side the emerging countries are competitors for the EU but on the other side they provide a huge market for 
the EU. The world financial institution system needs to be revised. The lack of responsibility and the easy access to bank loans led to the world financial crisis. Europe has to elaborate mechanism to monitor risks and set up an institution co-ordinating the procedure.

The climate change and energy sources management require drastic operation plan. The fossil energy dependency and the not efficient use of raw materials cause exaggerated energy dependency and generate national safety risks. The increasing world population accelerates the competition for raw materials and exhausts the environment. The EU has to co-operate with other regions of the world to stabilize the natural environment.

\section{Aalysing the budget period of the European Union between 2007-2013}

The total annual GDP of the EU makes up around 120 billion EUR amounting 1\% of the GDP of the member countries. The Structural and Cohesion Funds receive one third out of the total annual budget. The European Social Fund receives $8 \%$ of the total annual budget. The European Social Fund spends 75 billion EUR on establishment of quality jobs. The share of the structural funds within the total budget makes up $35 \%$ amounting 42 billion EUR. The GDP per capita determines whether a region or country belongs to the convergence or regional competitiveness target. In case of convergence regions, the co-financing of the European Social Fund can reach up to $80 \%$. The convergence target focuses on financing projects creating jobs and contributing to economic growth. In the framework of the regional competitiveness the European Social Fund provides subsidies to the labour markets of the regions so that they can get competitive on international level. The division of the European Social Fund depends on several factors. Member countries disposing of big population receive more funds. The convergence regions are provided more funds in all member countries. It is to be considered that the new member countries are provided more funds than the old member countries. This measurement is synchronised with the aim that the new member states have to close up and to accommodate their economies to the expectation of globalisation. In this respect can be seen the role of the European Social Fund to serve cohesion the best. The underdeveloped regions are subsidized so that a widespread cohesion within the EU can be reached. Analysing the budget period between 2007 and 2013 it can be assessed that the emphasis was laid on competitiveness. The funds spent on the provision of competitiveness for growth and employment increase by $6-7 \%$ annually. At the same time the common agricultural provision decreases by $3 \%$ annually (table 1 ).

Changes of the structure and priorities of the financial framework of the buget period 2000-2006 and 2007-2013. (million EUR at 2004 prices)

\begin{tabular}{lrrrrr}
\hline \multicolumn{1}{c}{ Liability provisions } & $\begin{array}{c}\text { 2000-2006 } \\
(2004 \text { prices })\end{array}$ & \multicolumn{1}{c}{$\%$} & \multicolumn{1}{c}{ Liability provision } & $\begin{array}{c}\text { 2007-2013 } \\
(2004 \text { prices })\end{array}$ \\
\hline 1. Agriculture & 330544 & $44.33 \%$ & 1. Sustainable growth & 382139 & $44.21 \%$ \\
1.a Common agriculture & 292287 & $39.20 \%$ & 1.a. Competitiveness for growth and employment & 74098 & $8.57 \%$ \\
1.b Rural development & 38257 & $5.13 \%$ & 1.b. Cohesion for growth and development & 308041 & $35.64 \%$ \\
2. Structural activities & 258656 & $34.69 \%$ & 2. Maintenance and handling of natural resources & 371344 & $42.96 \%$ \\
Struktural Funds & 230900 & $30.96 \%$ & Direct payments and expenditures connected to market & 293105 & $33.91 \%$ \\
Cohesion Fund & 27756 & $3.72 \%$ & 3. Citizenship, freedom, security & 10770 & $1.25 \%$ \\
3. Internal policies & 52439 & $7.03 \%$ & 3.a. Freedom, security, justice & 6630 & $0.77 \%$ \\
4. External actions & 34486 & $4.62 \%$ & 3.b Citizenship & 4140 & $0.48 \%$ \\
5. Administration & 38099 & $5.11 \%$ & 4. EU, as a global player & 49463 & $5.72 \%$ \\
6. Provisions & 4258 & $0.57 \%$ & 5. Administration & 49800 & $5.76 \%$ \\
7. Pre-accession subsidies & 23493 & $3.15 \%$ & 6. Compensation & 800 & $0.09 \%$ \\
8. Compensation & 3750 & $0.50 \%$ & & 864316 & $100.00 \%$ \\
\hline Liability provisions & 745725 & $200.00 \%$ & Liability provisions & & \\
\hline
\end{tabular}

Source: ICEG Working Paper (2007)

The first table exactly shows the structural changes in the liability provisions. Fundamental goal of the Treaty of Rome is to establish the European economic and political union. To achieve this goal the member states need to transfer several national rights to the union's level. The broadening tasks and aims of the European integration unambiguously need to increase the common budget of the EU. The different countrygroups dispose of different interests within the EU. The net in-payer countries consider the common budget as a base and not the common policies and targets. The net in-payers maintain the proportion of transfers and the characteristic representation of national interests.
On the contrary the beneficiaries of the common budget constantly maintain the strengthening of convergence and solidarity and the redistribution of the common budget. Due to the accession of the Mediterranean countries the common budget considerably changed. The peripheries required the redistribution of the funds of the EU. The convergence needs of the newly joined 12 Middle-Eastern European countries make the situation even more complicated because the funds to be redistributed decreased. The new member states are first of all interested in the close up and in strengthening the cohesion. Serious tensions are reckoned on among the peripheries - that are even today beneficiaries - and 
the core regions and the peripheries and the newly joined countries. Above that there are philosophical discrepancies. While the one point of view protects the markets the other attitude strives to foster competitiveness. The decision makers of the EU need to decide whether they further protect the developed core regions or they try to close up the undeveloped peripheries. It is to be decided which way of development the EU prefers: economic growth with considerable developmental differences or slower growth with narrowing developmental differences. Studying the Europe 2020 strategy it is unambiguous that the EU prefers strengthening the competitiveness in the global competition forecasting the two speeds Europe.

The measure of the common budget considerably changed during the last decades. 1965-1970 the common budget made up $0.4 \%$ of the GDP of the EU. Overwhelming part of the funds was spent on agriculture. 1985 the common budget rose up to $0.85 \%$ of the GDP of the EU, so it doubled (ICEG Working Paper, 2007).

At that time the provision for agriculture remained considerable with a share of $66 \%$. Due to the accession of the Mediterranean countries the structural policy became more and more important.
During the budget period 2007-2013 the own funds of the EU were fixed at $1.24 \%$ of the GDP of the European Union, while the expenditures make up $1.048 \%$ of the union's GDP.

\section{CONCLUSIONS}

Regarding the financial period between 2007-2013 it can be established that the emphasis is laid more and more on competitiveness. The funds stipulated for competitiveness targets grow by $6-7 \%$ yearly. At the same time the funds allocated for agriculture and rural development decrease by $3 \%$ yearly.

During the actual budgetary period the funds make up 347410 billion EUR. $81.5 \%$ of this amount are spent on convergence goals, $16 \%$ on competitiveness and $2.5 \%$ on territorial co-operation targets. Studying the current financial perspective tensions are likely to develop between the old and new member states (core regions - peripheries) because the emphasis shifted from the cohesion to the competitiveness targets and this occurrence hurts the Mediterranean countries and the new Middle-Eastern European countries member states.

\section{REFERENCES}

Resolution of the European Council for strategic guidelines concerning cohesion (2006/702/EK) (2006): Official Journal of the European Union. L291: 11.
ICEG Working Paper (2007): 20: 9 .

Communication from the Commission, Europe 2020 (2010): A strategy for smart, sustainable and inclusive growth. Brussels. 5. 
